\title{
PORELLA PERROTTETIANA (PORELLACEAE, MARCHANTIOPHYTA) A SPECIES FROM THE WESTERN GHATS OF KERALA
}

\author{
B. Mufeed and C. N. MAnju* \\ Department of Botany, Zamorin's Guruvayurappan College \\ (affiliated to the University of Calicut), Kozhikode-14, Kerala-673014, India \\ *E-mail: manjucali@gmail.com
}

(Received 1 November, 2016; Accepted 15 December, 2016)

Porella perrottetiana Trev. is reported from the Western Ghats of Kerala. This is the first record of this species from Kerala.

Key words: Kerala, little known, new record, Porella perrottetiana, Porellaceae

\section{INTRODUCTION}

Porella is the best known and widely distributed tropical genus of the order Porellales with about 60 species in the world and 27 taxa in India (Dandotiya et al. 2011, Daniels 2010, Nair et al. 2005, Singh and Nath 2007, Singh and Singh 2006, 2015). Chopra (1943) recorded a few species from South India. Most of the genera earlier reported from South India were under Madotheca and Hattori $(1978,1979)$ synonymised all the species known under Madotheca to Porella. Hence a total of eight species, one variety and one subspecies viz., Porella acutifolia (Lehm. et Lindenb.) Trevis. var. acutifolia, Porella caespitans (Steph.) S. Hatt. var. cordifolia (Steph.) S. Hatt., Porella campylophylla (Lehm. et Lindb.) Trevis. subsp. campylophylla, Porella campylophylla (Lehm. et Lindb.) Trevis. subsp. lancistipula (Steph.) S. Hatt., Porella chinensis (Steph.) S. Hatt. var. chinensis, Porella chinensis (Steph.) S. Hatt. var. irregularis (Steph.) S. Hatt., Porella kashyapii (R. S. Chopra) Kachroo, Porella madagascariensis (Nees et Mont.) Trevis., Porella perrottetiana (Mont.) Trevis. var. perrottetiana, Porella plumosa (Mitt.) Inoue were reported from Tamil Nadu, all these known under Madotheca until 1978. From Kerala only three species viz., Porella acutifolia 
(Lehm. et Lindenb.) Trevis., Porella caespitans (Steph.) S. Hatt., Porella campylophylla (Lehm. et Lindenb.) Trevis. are reported (Nair and Madhusoodanan 2006, Nair et al. 2005, 2006, Pócs et al. 2007).

Porella perrottetiana (Mont.) Trevis. is first collected from Nielgheri Hills in Tamil Nadu (Montagne 1842). After Montagne's report this species was collected by several authors from different areas of Tamil Nadu, such as Kotagiri and Shembaganur (Chopra 1938). All known under Madotheca perrottetiana. This species was also collected from Ootacamund and Kodaikanal (Hattori 1967) and Dodabetta (Hattori 1969). Hattori (1978) synonimised Madotheca
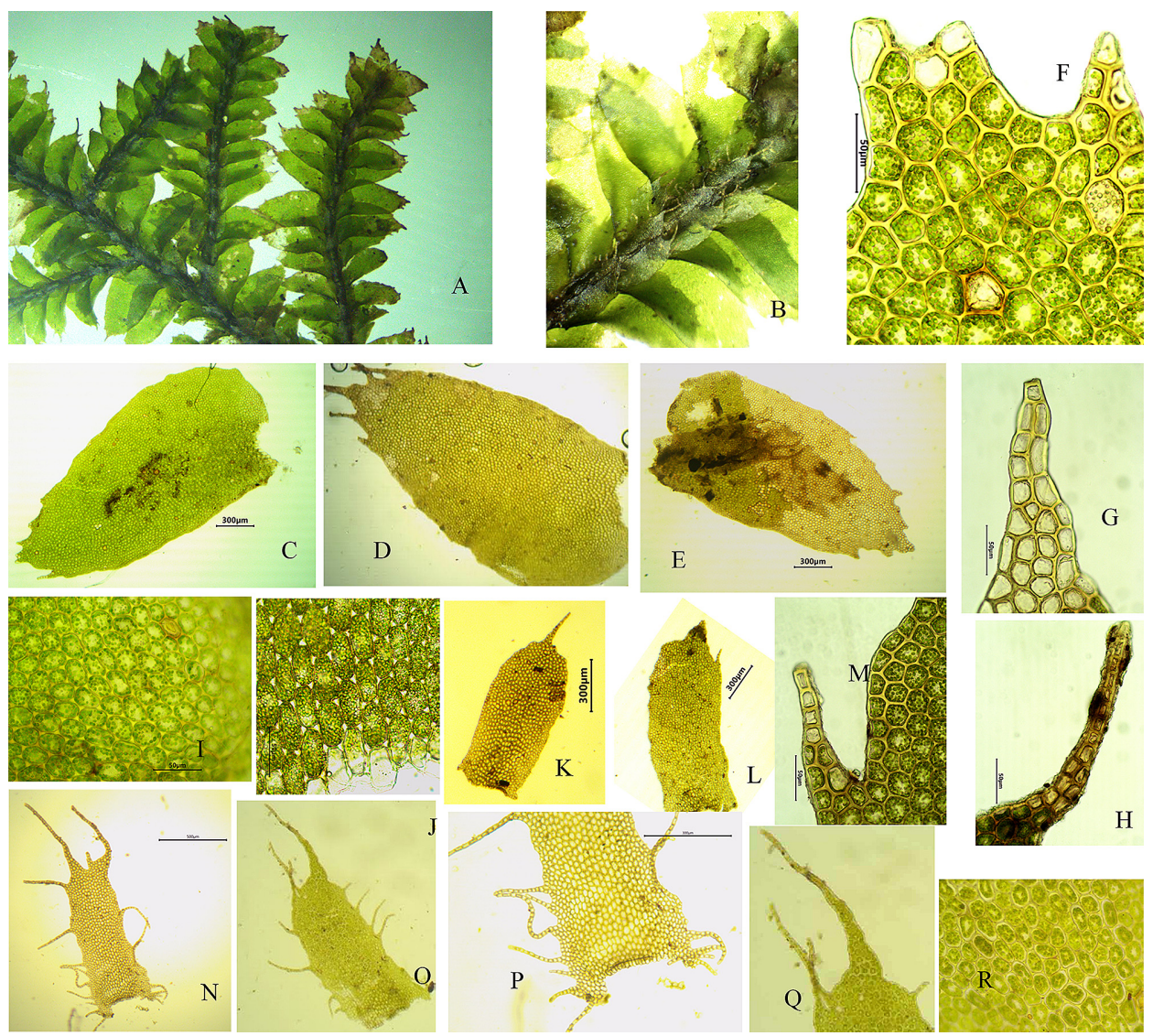

Fig. 1. Porella perrottetiana. $\mathrm{A}=$ habit dorsal view; $\mathrm{B}=$ branch ventral view; $\mathrm{C}-\mathrm{D}=$ leaf lobe; $\mathrm{E}=$ leaf lobule attached to lobe; $\mathrm{F}=$ leaf tip cells; $\mathrm{G}, \mathrm{H}, \mathrm{M}=$ leaf tip spines; $\mathrm{I}=$ leaf middle cells; $\mathrm{J}=$ leaf basal cells; $\mathrm{K}-\mathrm{L}=$ underleaves; $\mathrm{N}-\mathrm{O}=$ leaf lobules; $\mathrm{P}=$ leaf lobule base; $\mathrm{P}=$ leaf lobule tip; $\mathrm{Q}=$ underleaf cells 
perrottetiana under Porella perrottetiana. Later Udar and Shaheen (1983) reported this species from Nilgiris and Ootacamund in Tamil Nadu. Daniels (2010) listed this species based on earlier collections. After a long gap of 30 years we could collect this species from Anamudi Shola National Park of Western Ghats in Kerala State. The species is described in detail with photographs.

\section{Porella perrottetiana (Mont.) Trevis.}

(Fig. 1)

Basionym: Madotheca perrottetiana Mont., Ann. Sci. Nat., Bot., sér. 2. 18: 15 (1842). झ Porella perrottetiana (Mont.) Trevis., Mem. Reale 1st Lombardo Sci. Ser. 3 Cl. Sci. Mat. 4: 408 (1877).

Plants pale greenish to brownish green, branching pseudo-dichotomous, branches short; stem 4-6 cm long and 2-3 mm wide including leaves, creeping or ascending; branches 3-3.5 mm long, leaf lobes opposite, 6-8 $\mathrm{mm}$ long, imbricate to ovate oblong, apex narrow, 5-6 spines; spines unequal, not parallel, spines with single cell in lateral side, apical spines with 8 or 9 long cells of $39-42 \times 17-20 \mu \mathrm{m}$ in size, basal cells with 2-4(5) rows of rhomboidal cells; mid laminal cells more or less spherical, $80-95 \mu \mathrm{m}$ diagonally; mid basal cells rectangular, $40-48 \times 21-28 \mu \mathrm{m}$; presence of trigones, trigones prominent at basal cells; leaf lobules attached to leaf lobe at the extreme base, ligulate-ovate lanceolate with narrow apex; $1.15-1.30 \mathrm{~mm} \times 45-50 \mathrm{~mm}$; spines very few in lobule compared to underleaf, apical spine $0.20-0.30 \mathrm{~mm}$ long; oil bodies over 25 per leaf cell, homogenous, spherical, $4-6 \mu \mathrm{m}$ in diameter; underleaves 1.5-1.7 $\mathrm{mm} \times 0.30-0.35 \mathrm{~mm}$, broader than stem, $1.50-1.65 \mathrm{~mm}$ long including spines, 15-18 number of spines present throughout the margin, spines $0.13-0.65 \mathrm{~mm}$ long. Spines present at tip with $0.6-0.7 \mathrm{~mm}$ long.

Habitat and distribution: It is predominantly a high altitude species found growing on the bark of trees creeping and the branches are ascending (and growing rarely also on rock cliffs). This species was earlier reported from Tamil Nadu in India and China, Japan and Vietnam (also at relatively low altitudes with climate wet enough).

Acknowledgements - The authors are thankful to Dr D. K. Singh (Rtd.), Scientist G, Botanical Survey of India, Kolkata for confirming the identity of the species. One of the authors $(\mathrm{MCN})$ acknowledges SERB-DST (Department of Science \& Technology), New Delhi and Kerala State Council for Science Technology \& Environment (KSCATE), Thiruvananthapuram for providing financial assistance. We are also thankful to the authorities of the Zamorin's Guruvayurappan College for providing facilities and encouragement. 


\section{REFERENCES}

Chopra, R. S. (1938): Notes on Indian Hepatics I. South India. - Proceeds Indian Acad. Sci., Ser B, 7: 239-251.

Chopra, R. S. (1943): A census of Indian Hepatics. II. - J. Indian Bot. Soc. 22: 237-259.

Dandotiya, D., Govindapyari, H., Suman, S. and Uniyal, P. L. (2011): Checklist of the bryophytes of India. - Arch. Bryol. 66: 1-126.

Daniels, A. E. D. (2010): Checklist of the bryophytes of Tamil Nadu, India. - Arch. Bryol. 65: $1-118$.

Hattori, S. (1967): Studies of the Asiatic species of the genus Porella (Hepaticae). - J. Hattori Bot. Lab. 30: 129-151.

Hattori, S. (1969): Studies of the Asiatic species of the genus Porella (Hepaticae). II. - J. Hattori Bot. Lab. 32: 319-359.

Hattori, S. (1978): Studies on the Asiatic species of the genus Porella (Hepaticae). VII. A synopsis of Asiatic Porellaceae. - J. Hattori Bot. Lab. 44: 91-120.

Hattori, S. (1979): Corrections of names of Porella taxa. - Misc. Bryol. Lichenol. 8: 79.

Montagne, J. P. F. C. (1842): Cryptogamae Nilgherienses Plantarum cellularium in montibus peninsulae Indicae Neel-Gherries dictis a cl. Perrottet collectarum Enumeratio, Hepaticae. - Ann. Sci. Nat., Bot. 2, 18: 12-17.

Nair, M. C. and Madhusoodanan, P. V. (2006): A preliminary survey of the bryophyte flora of Vellarimala in Western Ghats of Kerala. - Indian J. Forestry 29(2): 191-196.

Nair, M. C., Rajesh, K. P. and Madhusoodanan, P. V. (2005): Bryophytes of Wayanad in Western Ghats. - Malabar Natural History Society, Kozhikode, 284 pp.

Nair, M. C., Rajesh, K. P. and Madhusoodanan, P. V. (2006): Addition to the bryoflora of Peninsular India. - J. Econ. Tax. Bot. 30(2): 221-224.

Pócs, T., Nair, M. C., Rajesh, K. P. and Madhusoodanan, P. V. (2007): Liverwort (Marchantiopsida) records from the Western Ghats (Kerala State, Peninsular India). - Acta Bot. Hung. 49: 121-129. https://doi.org/10.1556/ABot.49.2007.1-2.13

Singh, A. P. and Nath, V. (2007): Hepaticae of Khasi and Jaintia hills: Eastern Himalayas. Bishen Singh Mahendra Pal Singh, Dehra Dun.

Singh, S. K. and Singh, D. K. (2006): Contribution to the bryoflora of Great Himalayan National Park, Kulu, Himachal Pradesh IV: Genus Porella (Porellaceae). - Geophytology 36: 93-107.

Singh, D. K. and Singh, S. K. (2015): Manual of liverworts \& hornworts of Himachal Pradesh, India. - Bishen Singh Mahendra Pal Singh, Dehra Dun, 205 pp.

Udar, R. and Shaheen, F. (1983): Morpho-taxonomy of Porella perrottetiana (Mont.) Trev. from South India. - J. Indian Bot. Soc. 62: 319-325. 